\title{
Paracel Islands
}

National Cancer Institute

\section{Source}

National Cancer Institute. Paracel Islands. NCI Thesaurus. Code C123768.

A group of small islands and reefs in the South China Sea, between Vietnam and the Philippines. 